\title{
The role of the Belgian Council of State as a cassation court in light of judicial protection against government action
}

\section{Elsbeth Loncke *}

\author{
Aanbevolen citeerwijze bij dit artikel \\ Elsbeth Loncke, 'The role of the Belgian Council of State as a cassation court \\ in light of judicial protection against government action', NALL november \\ 2016, DOI: 10.5553/NALL/.000026
}

\section{A. Introduction}

A cassation court traditionally has two tasks: a unifying task and a corrective task. The unifying task consists of verifying the internal legality of a lower court's decision. The cassation court supervises the correct application and interpretation of the law by the lower courts, i.e. guaranteeing the unity of jurisprudence. The corrective task refers to verifying the external legality of the lower court's decision. The cassation court must ensure that the decisions of the courts concerned are in conformity with the requirements of proper administration of justice. The cassation court checks whether the procedure before the lower court has been properly conducted and whether this court's judgment has been properly motivated.

This article focuses on the following research question: is it necessary that the Belgian Council of State, acting in the capacity of a cassation court, perform both traditional tasks (corrective and unifying)? This is by no means self-evident, given the specific judicial structure in which the Council of State operates.

In order to answer this question, I will first examine the recent evolution in the organization of administrative justice in Flanders and Belgium and the consequences of this evolution for the cassation jurisdiction of the Council of State.

Second, I will explore the two traditional tasks of a cassation court in detail.

Third, I will examine whether the Council should exercise a unifying function. The answer to this question primarily depends on the extent 
to which the legislator can guarantee the unity of jurisprudence prior to the cassation procedure. The more unity of jurisprudence exists between the high administrative courts, the less the need for a cassation court that ensures the unity of jurisprudence at a higher level. Hence, I will research the risk of conflicts of jurisprudence between the Flemish high administrative courts prior to the cassation procedure.

Fourth, I will examine whether there is a need for the Council of State to perform a corrective task. This is largely determined by the judicial protection citizens enjoy prior to the cassation procedure. The higher the judicial protection before the high administrative courts, the less the need for a cassation court to monitor the proper administration of justice. I will therefore examine the legal protection citizens enjoy prior to the cassation procedure before the Council of State. I will devote special attention to the lack of an appeal procedure against a decision of a high administrative court, the question whether a nonjurisdictional administrative appeal has to be completed before one can lodge an appeal with a high administrative court, and the sanctions the administrative courts can impose on administrations that have issued illegal administrative acts.

\section{B. Recent evolution in the organization of administrative justice}

\section{Background}

While on the one hand, civil courts provide judicial protection against government action in Belgium, on the other hand the administrative courts do as well. ${ }^{1}$ The competence of these courts is allotted depending on the nature of the "actual and direct" object of the dispute. More specifically, civil courts settle "subjective" disputes or disputes concerning a subjective right, i.e. a right to a governmental performance that is a direct legal effect of a regulation, in the sense that the regulation defines the complete content and conditions of this performance so that there is no room for any discretionary appreciation by the government. ${ }^{\mathbf{2}}$ In contrast, ${ }^{\mathbf{3}}$ administrative courts settle "objective" disputes, i.e. disputes that do not concern subjective rights, but instead concern the legality of standards of objective law. 4 In this view, the existence and conferment of a right that leads to an objective dispute depend on a discretionary appreciation by the administration. $\mathbf{5}$

The Belgian Council of State (in its current form) ${ }^{\mathbf{6}}$ was established in $1946,7^{7}$ since when it has been the highest administrative court, competent to annul illegal administrative acts. In 1989 the Belgian legislator expanded the competence of the Council of State so that (under certain conditions) it could also suspend an administrative act, pending the decision concerning the annulment. ${ }^{\mathbf{8}}$ Alongside the Council of State existed other administrative courts with subject- 
matter jurisdiction, but these were often difficult to identify as they were mostly administrative institutions with limited judicial capacity. Consequently, it was not always self-evident whether a certain decision by this institution constituted an administrative act or a judicial decision. Moreover, not every administrative court was well known. The Belgian and Flemish administrative legislation is very diffusive, causing the specific, detailed administrative regulation and the administrative courts that resolve disputes arising from it, to be obscure. 9

Besides the power to annul and suspend administrative acts, the legislator also allocated the Council a cassation jurisdiction ever since 1946. ${ }^{10}$ This means the Council can annul jurisdictional decisions of other administrative courts. However, originally, the cassation jurisdiction was not always recognized or discussed as a separate jurisdiction in legal doctrine. In my opinion, this was for 4 reasons: 1) the annulment and cassation competence were provided in the same article of the relevant legislation; 2) the parliamentary preparations of this article were unclear, as it passed on the difficult task of distinguishing administrative from jurisdictional acts to the Council of State ${ }^{11}$; 3) the regulations on procedure were the same for the annulment and the cassation proceedings ${ }^{\mathbf{1 2}}$; 4 ) the Council of State originally used the same kind of assessment of the case facts, regardless of the capacity in which it acted (as an annulment or a cassation court). ${ }^{\mathbf{1 3}}$

\section{New high administrative courts}

In recent years, the Belgian and Flemish legislators have established several new administrative high courts that have taken over a large part of the annulment and suspension jurisdiction of the Council of State. The most important new high administrative courts are the Council for alien law litigation, ${ }^{\mathbf{1 4}}$ the Environmental Enforcement Court, ${ }^{\mathbf{1 5}}$ the Council for Permit Disputes ${ }^{\mathbf{1 6}}$ and the Council for Disputes about Decisions on Study Progress. ${ }^{17}$ One of the reasons for the creation of these courts is to be found in the judicial backlog of the Council of State in its capacity of annulment and suspension court, which had resulted in serious delays in the proceedings. ${ }^{\mathbf{1 8}}$ For example, in the judicial year 2005-2006 the number of pending cases before the Council of State amounted to 35.918 (24.946 concerning alien law and 10.866 in other areas of law). ${ }^{\mathbf{1 9}},{ }^{\mathbf{2 0}}$ Each of these high administrative courts has its own subject-matter jurisdiction. The Council for alien law litigation assesses with full jurisdiction administrative acts of the General Commission for Refugees and Stateless Persons (hereafter: “GCRS"). ${ }^{\mathbf{2 1}},{ }^{\mathbf{2 2}}$ When acting in the capacity of annulment and suspension court, the Council assesses other individual administrative acts taken in application of the Aliens Act, such as expulsion measures, decisions relating to visa, etc. ${ }^{23}$ The Environmental Enforcement Court appraises appeals 
against administrative fines, possibly together with a forfeiture of illegally acquired benefits, imposed to punish an environmental offence or infringement. ${ }^{\mathbf{2 4}}$ The Council for Permit Disputes assesses appeals against decisions concerning the allotment or denial of a building permit, validation decisions and registration decisions. ${ }^{25}$ Lastly, the Council for Disputes about Decisions on Study Progress can pronounce on disputes related to decisions on study progress in higher education, ${ }^{\mathbf{2 6}}$ such as (disciplinary) examination decisions and decisions concerning the award of an exemption to a study unit. ${ }^{27}$ The Council of State retains the residual competence to assess the legality of all other administrative acts.

The proceedings before each of these high administrative courts vary. For example, the time limit within which the administrative act has to be contested depends on the competent administrative court: for the Council for Permit Disputes it is 45 days from the day after the service of the permit decision or the day after the start of the public display of the permit decision ${ }^{\mathbf{2 8}}$; for the Council for alien law litigation ${ }^{\mathbf{2 9}}$ and the Environmental Enforcement Court it is 30 days from the day after the notification of the contested act ${ }^{\mathbf{3 0}}$; and for the Council for Disputes about Decisions on Study Progress it is 5 days from the day after the notification of the study progress decision. ${ }^{\mathbf{3 1}}$

Not only the judicial proceedings but also the precise (ruling) competence of the administrative courts differs. As mentioned above, the Council for alien law litigation acts as a court with full jurisdiction and as an annulment and suspension court, depending on the nature of the contested administrative act. In the capacity of a court with full jurisdiction, it re-examines the entire case after which it can reform or confirm the contested decision of the GCRS. ${ }^{32}$ However, as an annulment and suspension court, the Council limits its research to the legality of the contested administrative act. If it concludes that the act is illegal, it can pronounce the annulment thereof. ${ }^{\mathbf{3 3}}$ The Environmental Enforcement Court also limits its research to the legality of the contested administrative fines, ${ }^{\mathbf{3 4}}, \mathbf{3 5}$ but contrary to the Council for alien law litigation as an annulment court, it can not only (partly) annul the illegal decision concerning the fines. More specifically, the Court can also, if it sees fit, substitute the annulled fine with an own decision concerning the amount and, as the case may be, the forfeiture of illegally acquired benefits. ${ }^{\mathbf{3 6}}$ When the Council for Permit Disputes or the Environmental Enforcement Court (partly) annuls a contested act, it can order the administration that took this act to take a new administrative act within a certain period. In that case, the Council for Permit Disputes or the Environmental Enforcement Court can also $1^{\circ}$ designate specific rules or principles of law that have to be observed when taking the new administrative act; $2^{\circ}$ define the procedural actions that have to be taken prior to the new administrative act. ${ }^{37}$ Finally, the Council for Disputes about Decisions on Study Progress determines whether decisions on study progress are in accordance with the provisions of the Codification and regulations 
and the educational and examination regulations and with the general principles of good governance (legality check). ${ }^{38}$ If the contested decision on study progress is illegal, the Council, stating reasons, annuls it, in which case it can order the administration to take a conditioned new decision. 39

Finally, the territorial competence of the administrative high courts also varies. The Council for alien law litigation is a federal (Belgian) high administrative court, whereas the Council for Permit Disputes, the Environmental Enforcement Court and Council for Disputes about Decisions on Study Progress are regional (Flemish) high administrative courts.

It is obvious that the differences between the procedures and competences of these high administrative courts systems can cause confusion and legal uncertainty, which can result in a negative influence on the effective legal protection of the applicant. Therefore, the Flemish Decree 4 April 2014 concerning the organization and procedure of some Flemish administrative courts implements an umbrella structure under which the Council for Permit Disputes and the Environmental Enforcement Court resides, together with the Council for Election Disputes. ${ }^{\mathbf{4 0}},{ }^{\mathbf{4 1}}$ The Explanatory Memorandum on the draft of this Decree provides that this new structure aims, among other things, to standardize the procedures before these three courts governing, for example, time limits and ruling competence. However, the procedures remain different at some points. ${ }^{42}$ It is clear from the provisions of the Decree that the time limits and ruling competences of the administrative courts in fact remain to differ. The ruling competence of the Council for Permit Disputes and the Environmental Enforcement Court have indeed been more aligned than in the past. Since the Decree does not apply to the Council for alien law litigation $\mathbf{4 3}$ or the Council for Disputes about Decisions on Study Progress, it seems that the unifying effect of the Decree is necessarily limited.

\section{The importance of the cassation jurisdiction of the Council of State increases}

As mentioned above, not only is the Council of State an annulment and suspension court with respect to administrative acts, but it is also the competent cassation court with respect to judicial decisions of other administrative courts. ${ }^{44},{ }^{45}$ As a cassation court the Council of State "does not pronounce on the merits of the case," ${ }^{\mathbf{4 6}}$ which means it principally cannot assess the facts of the case. It is bound by the factual assessment of the case by the high administrative court, i.e. the court hearing the main action. $\mathbf{4 7}^{4}, \mathbf{4 8}$

On the one hand, the creation of the new high administrative courts led to a decrease in the annulment and suspension litigation before the Council of State. This is because these new courts acquired the competence to assess disputes that used to be assessed by the Council 
of State (disputes on alien law, construction permits, study progress decisions in higher education, administrative fines for environmental offence or infringement, ...). On the other hand, this led to an enormous increase in the importance of the cassation competence of the Council of State and its cassation jurisprudence. The Council of State may have lost the jurisdiction to annul and suspend certain administrative acts concerning alien law, construction permits, etc., but it gained the competence to issue cassation decisions in those same areas of law.

The legislator wanted to prevent serious delays in the annulment proceedings before the Council of State, which were solved via the creation of the administrative courts, from reappearing in the cassation proceedings. For this reason, the Act that created the Council for alien law litigation also thoroughly reformed the cassation procedure before the Council of State, introducing the so-called "cassation filter" or admissibility procedure in Art. 20 of the Organic Laws on the Council of State. ${ }^{49}$ The parliamentary preparations state that the admissibility procedure aims to prevent applicants from treating the Council of State (in the capacity of cassation court) as an appeal court, causing the Council to examine and settle appeals in cassation in main proceedings, while a short preliminary examination could have revealed that the grounds of cassation could never lead to the annulment of the contested judicial decision..$^{\mathbf{5}}$ Every cassation appeal (not only the cassation appeals against a judicial decision of the Council for alien law litigation) before the Council of State has to pass through the admissibility procedure before the Council can assess the substance of that appeal.

While the legislator introduced the admissibility procedure before the Council of State, the Royal Decree of 30 November 2006 implemented regulations of procedure, applicable only to the cassation proceedings. ${ }^{{ }^{\mathbf{1}}}$ Previously, the cassation proceedings took place in the same way as the annulment proceedings, as both were subject to the same regulations of procedure, i.e. the Regent's Decree of 23 August $1948 .^{2}$

The creation of the new high administrative courts and the subsequent increase in importance of the cassation competence of the Council of State, the introduction of the admissibility procedure and the separate regulation of procedure for the cassation proceedings led to a clear distinction between the annulment and the cassation jurisdiction of the Council of State.

\section{Tasks for the Council of State as a cassation court}

\section{Traditional tasks for a cassation court}

A cassation court traditionally has two tasks: a unifying task and a corrective task.

The unifying task consists of verifying the internal legality of the lower 
court's decision. The cassation court supervises the correct application and interpretation of the law by the lower courts, i.e. guaranteeing the unity of jurisprudence and thus the legal development and legal certainty. The corrective task refers to verifying the external legality of the lower court's decision. The cassation court must ensure that the decisions of the courts concerned are in conformity with the requirements of proper administration of justice. The cassation court checks whether the procedure before the lower court has been properly conducted and whether this court's judgment has been properly motivated.53

Legal doctrine usually discusses these two tasks in light of the Court of Cassation, which is the competent cassation court as regards ordinary (civil and penal) tribunals and courts, and emphasizes its unifying task.

It should be pointed out that in practice, the two tasks of a cassation court are not always so distinct as one might expect on the basis of the legal doctrine. Both tasks often overlap. For example, when the cassation court assesses a ground for cassation based on the infringement of the judicial obligation to state reasons (corrective task), the cassation court can - to the extent that this is meaningful in the light of the specific ground for cassation - give a certain interpretation of this obligation, which can also be used in other cases (unifying task).

To my knowledge, there is no legal doctrine that discusses the tasks of the Belgian Council of State as a cassation court (or similar institutions in other countries) in general, or the question of whether the traditional tasks of the Court of Cassation are applicable to the Council of State acting as a cassation court, in particular. The following sections therefore examine whether there is a need for a Council of State with the traditional functions of a cassation court, in light of the specific organization of the administrative justice in Flanders and Belgium.

\section{Council of State and the unifying task of the cassation court}

The need for a unifying task for the Council of State, acting as a cassation court, primarily depends on the extent to which the legislation can guarantee the unity of jurisprudence prior to the cassation procedure. The more unity of jurisprudence exists between the high administrative courts, the less need for a cassation court that ensures the unity of jurisprudence at a higher level.

As mentioned in section B.II., the new high administrative courts each have a subject-matter jurisdiction. This means that the areas of law, in which they pronounce their decisions, are strictly demarcated. At first sight, this implies that there is a much lower risk of conflicting jurisprudence between these courts in comparison with the traditional (ordinary) judiciary, where the competence between the courts is divided by subject-matter and by territory. Whereas the new high 
administrative courts are each unique, the traditional courts are not. For example, there are 13 Courts of First Instance in Belgium, each with the same subject-matter jurisdiction, but with distinct territorial jurisdiction. ${ }^{54}$ The same applies to the 5 Courts of Appeal. ${ }^{55}$ The Court of Cassation, which is the competent cassation court for the traditional judiciary, guarantees the unity of jurisprudence between these Courts of Appeal. However, the high administrative courts each have separate subject-matter jurisdiction and are unique in exercising it, so there is less need for a cassation court to substantively harmonize their jurisprudence.

Although the unifying task of the Council of State is of less importance than that of the Court of Cassation, it is certainly not entirely inexistent, because certain aspects of administrative law transcend the distinct subject-matters over which the high administrative courts rule. The supervision of the Council of State as a cassation court is useful and necessary in harmonizing lower jurisprudence concerning these aspects of administrative law. A clear example in this context are the general principles of good governance. Although these principles are unwritten, jurisprudence and legal doctrine unanimously agree that they are applicable to every administrative act, which means that each administration that issues an administrative act, regardless of the area of law that is concerned, has to respect them. Consequently, every high administrative court faces the general principles of good governance in its jurisprudence. Furthermore, for some high administrative courts, the legislator expressly provided that the general principles of good governance be included in the legality check of the contested administrative act. Art. II.291 Codification 11 October 2013 of the decree provisions on higher education, for example, states:

\author{
"The Council examines whether the disputed decisions are in \\ accordance with: \\ the provisions of the decree and regulations and the educational \\ and examination regulations; \\ general administrative principles and principles of good \\ governance"
}

Aspects of administrative law that transcend subject-matter include, for instance, calculation of time limits, consequences of annulment decisions, theory on retraction of administrative acts, and admissibility of annulment requests.

The interpretation of the high administrative courts concerning these aspects of administrative law can lead to conflicting jurisprudence. In this case, supervision by the Council of State as a cassation court with a unifying task is appropriate. 
Whether the Council of State should perform a corrective task is largely determined by the judicial protection citizens enjoy prior to the cassation procedure. The higher the judicial protection before the high administrative courts, the less need there is for a cassation court to monitor the proper administration of justice. It is therefore relevant to examine the legal protection citizens enjoy prior to the cassation procedure before the Council of State.

The following sections will devote special attention to the lack of a high appeal against a decision of a high administrative court, where cases are usually treated by a one-judge panel, the question of whether a non-jurisdictional administrative appeal has to be completed before one can make an appeal to a high administrative court, the injunction jurisdiction of high administrative courts, and the sanctions the administrative courts can impose on administrations that have issued illegal administrative acts.

\section{No high appeal possible against a decision of a high administrative court}

An important finding within the framework of legal protection by high administrative courts is that the legislator did not provide a high appeal against their decisions. The Council for alien law litigation, the Environmental Enforcement Court, the Council for Permit Disputes and the Council for disputes about decisions on study progress all have jurisdiction in first and last instance.

Although there is no obligation under Art. 6 European Convention on Human Rights for national States to provide a high appeal against judicial civil decisions of their courts, ${ }^{\mathbf{5 6}} \mathbf{5 7}$ the advantages of an appeal in light of judicial protection are obvious: it forms an extra guarantee of a proper administration of justice, since the appeal court can correct certain mistakes the court at first instance made concerning the proper administration of justice..$^{8}$

Furthermore, the standard cases before the high administrative courts are handled by a one-judge panel. This is the case for the Council for Permit Disputes, the Environmental Enforcement Court and the Court for alien law litigation. Only exceptional cases are handled by a threejudge panel. The treatment of the case by a one-judge panel prevents an internal monitoring of good administration of justice by other judges during the deliberation. This fact should lead to greater caution in the light of judicial protection of the parties involved.

\section{Non-jurisdictional appeal before the appeal to a high administrative court}

A non-jurisdictional appeal or internal appeal can be defined as an appeal that is lodged before an administration and that aims to have retracted, annulled or reformed an administrative act taken by that administration itself, a subordinate administration, an administration under supervision or another administration, or in case such 
administrative act has not yet been taken, to obtain such act. ${ }^{59}$ On the contrary, a judicial appeal is an appeal before an institution of the traditional judiciary, an administrative court or even a body of the administration that exercises a judicial function, and that leads to a decision with a specific scope that - based on a rule of law and with the force of res judicata - puts an end to a dispute. ${ }^{\mathbf{6 o}}$ One could state that the lack of a high appeal against decisions of a high administrative court could be remedied by the fact that a nonjurisdictional appeal has to be completed before an admissible (judicial) appeal can be lodged before this court. In this case, after all, two separate institutions examine the case in question. However, this line of thought is not convincing, for two reasons.

First, the internal appeal does not exist in every area of administrative law, and as a result, the admissibility condition of exhausting the internal appeal does not apply to applicants before every high administrative court. For instance, neither the Environmental Enforcement Court nor the Council for alien law litigation assesses administrative acts ruled on internal appeal. The legislator provided a direct judicial appeal against the relevant acts, without a prior internal appeal. This finding is very relevant, since $91.16 \%$ of the cassation appeals lodged before the Council of State are aimed against judicial decisions of the Council for alien law litigation. ${ }^{\mathbf{6 1}}$

Second, an administrative appeal can never provide the same guarantees to judicial protection as a judicial appeal. ${ }^{\mathbf{6 2}}$ (In fact, the term "judicial" protection is not even applicable to administrative appeals as they are assessed by an administration and not a judicial body ${ }^{63}$ ). The acts of an administration (such as an administrative review body) have to comply with the legal provisions and the general principles of good governance, e.g. the principle of impartiality, the (substantive and formal) duty to state reasons, the obligation to hear and the principle of reasonable time. However, the general principles of good governance are usually unwritten and consequently offer less protection than the supranational, constitutional or legal provisions that apply the same obligation to the (administrative) judiciary. ${ }^{64}$ Moreover, it is possible for a legal provision to derogate from an unwritten general principle of good governance, but obviously not from constitutional provisions or Art. 6 European Convention on Human Rights. ${ }^{65}$

In addition, certain guarantees of judicial protection apply only to judicial decisions but not to administrative (review) acts, unless this is explicitly provided by a legal provision: judicial independence, ${ }^{\mathbf{6 6}}$ prohibition on the removal of members of the judiciary, ${ }^{\mathbf{6}}$ the adversarial debate, the obligation to render a judicial decision, under penalty of being pursued, ${ }^{\mathbf{6 8}}$ the public hearings and rulings ${ }^{\mathbf{6 9}}$, etc. Some general principles of good governance or explicit legal provisions applicable to administrations are similar to certain judicial obligations, but offer less guarantees of judicial protection. For instance, Art. 149 Belgian Constitution imposes a judicial duty to state 
reasons. The Act of 29 July 1991 concerning the explicit motivation of government acts ${ }^{70}$ also imposes a duty to state reasons to administrations, but not for every administration and not for every administrative act. In particular, only the administrations referred to in Art. 14 Organic Laws on the Council of State have to formally motivate their written, unilateral, individual administrative acts. ${ }^{\mathbf{1}}$ Furthermore, the judicial duty to state reasons has a larger scope than the Act of 29 July 1991: the judiciary is obligated to answer all arguments, brought forward by the parties, whereas - according to established jurisprudence of the Council of State, acting as an annulment court - an administrative review body does not. An "adequate" motivation suffices, which implies that the motivation makes it possible for the citizen to comprehend why the administrative review body ruled as it did, contrary to his own argumentation, and enables him to make an informed decision on whether to appeal the review act. ${ }^{\mathbf{2}}$

In other words, a judicial appeal offers more guarantees of judicial protection than a non-judicial appeal.

Moreover, a judicial decision has force of res judicata, which according to the definition of MAST and others implies that the decision has become unalterable once the relevant conditions are met, unless the ordinary or extraordinary appeals are used. In principle, the judicial body that has rendered the decision cannot retract or reform it once it has force of res judicata. ${ }^{73}$ On the contrary, an administrative act does not enjoy force of res judicata, which means that the administration (such as an administrative review body) that has taken this act, can also - under certain conditions - retract or abrogate it. ${ }^{74}$ Also, there is always a chance that the Council of State (acting as an annulment court), another high administrative court with annulment jurisdiction or the supervising administration will annul an administrative act. Hence, a judicial decision offers the judiciable a greater legal certainty than an administrative act, because the settlement of the dispute by the judiciary will in principle be final, 75 unless an appeal is lodged against it.

\section{Injunction competence and sanctions}

Section B.II. has already discussed the sanctions the different high administrative courts can impose on administrations that have taken an illegal administrative act.

In the capacity of a court with full jurisdiction, the Council for alien law litigation re-examines the entire case, after which it can reform or confirm the contested decision of the GCRS. ${ }^{76}$ On the contrary, as an annulment and suspension court, the Council can only pronounce the annulment thereof. 77 The Environmental Enforcement Court can (partly) annul the illegal decision concerning the fines but can also, if he sees it fit, substitute the annulled fine with an own decision concerning the amount and, as the case may be, the forfeiture of 
illegally acquired benefits. ${ }^{78}$ The Council for Permit Disputes can annul the illegal contested permit-, validation- or registration act.79 When the Council for Permit Disputes or the Environmental Enforcement Court (partly) annuls a contested act, it can order the administration that took this act to take a new administrative act within a certain period. In that case, the Council for Permit Disputes or the Environmental Enforcement Court can also $1^{\circ}$ designate specific rules or principles of law that have to be observed when taking the new administrative act; $2^{\circ}$ define the procedural actions that have to be taken prior to the new administrative act. ${ }^{\mathbf{8 0}}$ Finally, the Council for Disputes about Decisions on Study Progress can annul the contested decision on study progress, in which case he can order the administration to take a new decision under conditions to be imposed by him. ${ }^{\mathbf{8 1}}$

Hence the annulment jurisdiction of most high administrative courts is accompanied by a (limited) injunction competence, since they can either substitute the contested decision with their own (Environmental Enforcement Court), or give strict conditions under which the administration has to take a new act (Environmental Enforcement Court, Council for Permit Disputes and Council for Disputes about Decisions on Study Progress). In light of procedural economy, these competences should be welcomed. A fortiori, the same applies to the competence of the Council for alien law litigation when acting in the capacity of a court with full jurisdiction.

\section{Conclusion}

There is no high appeal possible against decisions of high administrative courts, but only a cassation appeal before the Council of State. The judiciable does not enjoy an extra guarantee of proper jurisdictional protection prior to the cassation proceedings. The fact that most high administrative courts enjoy a (limited) injunction competence does not affect this conclusion. At most (but certainly not always), he can lodge a non-jurisdictional appeal against an administrative act, prior to his appeal before a high administrative court, but this kind of appeal can never offer the same guarantees as a judicial appeal. Furthermore, in most high administrative courts the standard cases are handled by a one-judge panel, which should lead to greater prudence in the light of judicial protection of the parties involved.

The lack of judicial appeal against decisions of a high administrative court, and thus the lack of a substantive double judicial review, justifies the corrective task of the Council of State acting as a cassation court.

\section{Should the legislator replace the administrative cassation appeal with a high appeal?}

Given the conclusion of section C.III.4., the question arises as to 
whether it would be preferable to substitute the cassation appeal before the Council of State with a high appeal before an appeal court, since an appeal court can evoke the entire case and re-examine it substantially. Thus an appeal court can provide a larger scope of judicial protection than a cassation court.

Apparently, the legal doctrine considers the lack of high appeal against decisions of high administrative courts self-evident. This is probably because of the possibility to lodge a non-judicial appeal prior to the appeal before the high administrative court, resulting in a double review (one non-judicial, one judicial) of the case in question. However, the fact remains that 1) the legislator does not always provide a non-judicial appeal, and 2) the non-judicial appeal can never provide the same guarantees of judicial protection as a judicial appeal. In light of the judicial protection, replacing the cassation appeal against decisions of high administrative courts with a high appeal should be considered. Nonetheless, doing so would cause the following difficulties:

1. It is not obvious which body could act as a high appeal court. In any case, it is not preferable that the Council of State would function as a high appeal court. The recent creation of the new high administrative courts was exactly aimed at reducing the Council's backlog (as an annulment and suspension court). Designating the Council as a high appeal court would reintroduce the same litigation, with the only difference that this time the Council is not the court at first instance, but the appeal court. ${ }^{82}$ This would lead to an unacceptable risk of increase of workload and backlog. In this context it must be reminded that the Council would still have to perform other tasks, next to functioning as an appeal court. The Council retains at present, and would still retain in case of the allotment of an appeal competence, the residual competence to assess the legality of administrative acts that are outside the scope of the high administrative courts.

It would be more eligible to create new, separate administrative high appeal courts, each competent to assess high appeals against the decisions of a particular high administrative court.

2. The need for an administrative cassation court would not disappear following the creation of administrative high appeal courts.

First, the Belgian Constitutional Court made it clear that the possibility of a cassation appeal with the Council of State against decisions of regional administrative courts is a necessary condition for the compatibility of these courts with the Constitution. ${ }^{83}$ 
Second, an appeal court is focused mainly on the substantive aspects of the case, and not on ensuring the unity of jurisprudence. As discussed in section C.II., it is clear that there is a need for a body that guarantees the unity of administrative jurisprudence, but this is not a task for a high appeal court. In other words, the creation of administrative high appeal courts would not make the Council of State as a cassation court obsolete, but would limit its tasks. First, there would be less need for a cassation court with a corrective task. Second, there would still be a need for a cassation court with a unifying task, although this task would be less important for the Council of State than it would be for the traditional cassation court of the civil and penal judiciary, given the strict subject-jurisdiction of the administrative (high appeal) courts.

3. The creation of an appeal against decisions of administrative courts would prolong the duration of the entire proceedings, leading to an increased risk of infringement of the judicial duty to settle the dispute within a reasonable period (Art. 6 European Convention of Human Rights).

4. The creation of an appeal against decisions of administrative courts could lead to legal uncertainty, especially when the citizen has lodged an internal appeal prior to lodging an appeal before an administrative court. In this case, he has to undergo three reviews of this case (internal appeal - appeal before an administrative court - appeal before an administrative appeal court) before he can receive a definite ruling, which can still be brought before the Council of State as a cassation court. In light of the principle of legal certainty, this situation is not desirable. The same goes for the administration who is a party in the legal dispute: legal certainty is of equal importance for the administration who took the administrative decision that is the original of the legal dispute at hand.

\section{E. Conclusion}

The specific organization of the administrative justice in Flanders and Belgium justifies that the Council of State, acting as a cassation court, exercise both a unifying and a corrective task. However, the corrective task is of more relevance in comparison with the Court of Cassation. The creation of administrative appeals courts would not render the Council of State as a cassation court obsolete, but would limit its aforementioned tasks. Moreover, it would raise some serious concerns, e.g. relating to the duty to settle the dispute within a reasonable period and relating to legal certainty. 
* The text was written for the annual EGPA conference that took place from 10 to 12 September 2014 in Speyer, Germany. It was updated and finalized on 15 October 2016.

1 Art. 144-145-146 and 160 of the Belgian Constitution; D. VERBIEST, Jurisdictionele rechtsbescherming: monistische droom en dualistische realiteit, 5 TIJDSCHRIFT VOOR BESTUURSWETENSCHAPPEN EN PUBLIEKRECHT (TBP) 278 (2009); S. LUST, Rechtsherstel door de Raad van State, 62 (2000).

2 Council of State (CoS) 18 March 1969, nr. 13.45o, Marneffe; CoS 3 June 1980, nr. 20.377, Lemmens; CoS 10 March 1987, Goossens; CoS 10 December 2012, nr. 221.671, Cooman; CoS 18 October 2012, nr. 221.098, Hasalla; CoS 5 December 2011, nr. 216.681, Biomassa Centrale Ieper; CoS 28 October 2011, nr. 216.105, Antkowiak.

3 A part of the Belgian legal doctrine considers the division between subjective and objective disputes artificial and therefore believes it should be abandoned. J. GOOSSENS and J. MOLLIN, Vlinderakkoord kondigt hertekening gerechtelijk landschap aan via artikel 144 Grondwet, 1 CHRONIQUES DE DROIT PUBLIC/PUBLIEKRECHTELIJKE KRONIEKEN (CDPK) 78, 85 (2012); M. VAN DAMME, Gerechtelijke hervorming en de administratieve rechtsbedeling, in, DE GERECHTELIJKE HERVORMING, 43, 60 (Hubert Bocken ed. 2012); A-S VANDAELE, Bezint eer gij begint: enkele bedenkingen bij de herziening van artikel 144 G.W., 2 CDPK 263, 266 (2012); D. D'HOOGHE and L.

SCHELLEKENS, De interferentie tussen kortgedingprocedures bij de Raad van State en gerechtelijke procedure voor andere rechtsmachten, in RECHTSBESCHERMING DOOR DE RAAD VAN STATE. 15 JAAR PROCEDURELE VERNIEUWING, (G. DEBERSAQUES , M. VAN DAMME, S. DE CLERCQ and G. LAENEN eds., 2005), 221, 223; A. COPPENS, De volmaakte rechtsstaat, 32 RECHTSKUNDIG WEEKBLAD (RW) 1241, 1249 (2002-03); C. BERX, RECHTSBESCHERMING VAN DE BURGER TEGEN DE OVERHEID nr. 296 (2000); S. LUST, RECHTSHERSTEL DOOR DE RAAD VAN STATE (2000); LE CONSEIL D'ETAT DE BELGIQUE. CINQUANTE ANS APRÈS SA CRÉATION 159 (B. Blero ed., 1999). This critique has become even more relevant since the alteration of Art. 144 of the Belgian Constitution in 2014. This article now provides that the legislator can empower the Council of State or the federal administrative courts (who settle objective disputes) to decide on the civil consequences of their decisions.

4 OVERZICHT VAN HET BELGISCH ADMINISTRATIEF RECHT 1041 (A. MAST, J. DUJARDIN, M. DAN DAMME, J. VANDE LANOTTE eds., 2014). 
6 Since 1531, several institutions have been named "Council of State" (Raad van State), although substantively they do not compare with the current Council of State. For further information on the historical background of the Council: M. MAGITS, De Raad van State in historisch perspectief, in DE ADVIESBEVOEGDHEID VAN DE RAAD VAN STATE 4 (L. WINTGENS ed., 2003); A. VANDER STICHELE, Administratieve rechtspraak in België, in, HONDERDVIJFTIG JAAR RECHTSLEVEN IN BELGIË EN NEDERLAND (1830-1980), 382 (E.G. SPANOGHE and F. FEENSTRA eds., 1981); M. BAELDE, Les Conseils Collatéraux des anciens Pays-Bas, 1 REVUE DU NORD 203, 204 (1968); M. BAELDE, DE COLLATERALE RADEN ONDER KAREL V EN FILIPS II (1531-1578) 24 (1965); H. VELGE, L'INSTITUTION D'UN CONSEIL D'ETAT EN BELGIQUE, 23 (1930); H.J.A. MULDER, DE RAAD VAN STATE. HISTORISCHSTAATSRECHTELIJKE PROEVE VAN VERGELIJKENDE RECHTSSTUDIE, 173 (1889).

7 Act 23 December 1946 on the creation of a Council of State, Belgian Official Gazette (BOG) 9 January 1947.

8 Art. 15 Act 16 June 1989 on various institutional reforms, BOG 17 June 1989; Art. 17-18 Organic laws on the Council of State, coordinated by the Royal Decree of 12 January 1973, BOG 21 March 1973 (Organic laws on the Council of State).

\section{I. SIRJACOBS and H. VANDEN BOSCH, DE ADMINISTRTATIEVE RECHTSCOLLEGES IN BELGIË SINDS 1795, 84-127 (2006).}

10 Art. 9 Act 23 December 1946 on the creation of a Council of State, BOG 9 January 1947; Art. 14, § 2 Organic laws on the Council of State.

$\mathbf{1 1}$ This led some doctrine to conclude that there is no difference between an administrative act and an administrative jurisdictional decision. M. SOMERHAUSEN and E. VANHAESEDONCK, Le Conseil d'Etat, REVUE DE DROIT COMMUNAL 115, 128 (1948).

12 Regent's Decree of 23 August 1948 establishing the procedure before the Administrative Section of the Council, BOG 23-24 August 1948, err. BOG 8 October 1948 and 21 November 1948.

13 X., LES NOVELLES. DROIT ADMINISTRATIF. TÔME VI, 588 (1975), with references to jurisprudence.

14 Act 15 September 2006 on the reform of the Council of State and on the creation of a Council for alien law litigation, BOG 6 October 
2006.

15 Art. 9 Act of 21 December 2007, which supplements the decree of 5 April 1995 containing general provisions on environmental policy with a Title XVI 'Monitoring, Enforcement and Safety Measures', BOG 29 February 2008.

16 Art. 4.8.1. Flemish Codex on Zoning Law, BOG 20 August 2009, err. BOG 27 June 2012.

17 Art. II.15 Act of 19 March 2004 concerning the arrangement of the legal position of the student, BOG 10 June 2004, err. BOG 27 July 2004, replaced by art. II.285 Codification 11 October 2013 of the decree provisions on higher education, BOG 27 February 2014.

18 For example, see: Explanatory Memorandum on the draft Act on the reform of the Council of State and on the creation of a Council for alien law litigation, Parl. St. Kamer, 51-2479/001, 10 and following.

19 Annual Report Council of State 2005-2006, 18.

20 The creation of new high administrative courts aimed at reducing the overload before the Council of State has proved to be very successful. In the judicial year 2014-2015 the number of pending cases before the Council of State (as an annulment and suspension court) amounted to 4.279. (Annual Report Council of State 2014-2015, 11)

21 Art. 39/2§1 Act of 15 December 1980 on the access to the territory, stay, establishment and return of the foreigners, BOG 31 December 1980 (Aliens Act). For certain decisions of the GCRS, the Court acts as an annulment court. (Art. 39/2§1, third paragraph)

22 The GCRS is the central asylum authority, and since 1 June 2007 it is the only body competent to study asylum applications. It grants refugee status or subsidiary protection status.

23 Art. 39/2§2 Aliens Act.

24 Art. 16.4.19§2 Decree of 5 April 1995 containing general provisions on environmental policy, BOG 3 June 1995; available at: http://www.mhhc.be/en.

25 Art. 4.8.2. Flemish Codex on Zoning Law. Validation decisions are administrative acts that (refuse to) validate an "as-built-certificate". Registration decisions are administrative acts that (refuse to) register a building "as being deemed to have been permitted" in the permit register. 
26 Art. II.285 Codification 11 October 2013 of the decree provisions on higher education, BOG 27 February 2014.

27 Art. I.3, $69^{\circ}$ Codification 11 October 2013 of the decree provisions on higher education, BOG 27 February 2014.

28 Art. 4.8.11§2 Flemish Codex on Zoning Law.

29 In some cases, however, the time limit is 15 days. Art. 39/57§1, 2nd paragraph Aliens Act.

30 Art. 39/57§1, first paragraph Aliens Act; Art. 16.4.39 and 16.4.44 Decree of 5 April 1995 containing general provisions on environmental policy, BOG 3 June 1995.

31 Art. II.294 Codification 11 October 2013 of the decree provisions on higher education, BOG 27 February 2014.

32 Art. 39/2§1, second paragraph Aliens Act. Under certain conditions, the Council can annul the contested act and send the case back to the GCRS, which will have to take a new administrative act.

33 The applicant can also request the suspension of the contested act, as an adjunct to the annulment.

34 Possibly together with a forfeiture of illegally acquired benefits.

35 C. BILLIET, Punitieve handhaving in de bestuursrechtspraak: recente rechtspraak van het Milieuhandhavingscollege, 2 TIJDSCHRIFT VOOR MILIEURECHT (TMR) 117, 119 (2013).

36 Art. 44. Flemish Decree 4 April 2014 on the organization of and the proceedings before certain Flemish administrative courts, BOG 1

October 2014.

37 Art. 37 Flemish Decree 4 April 2014 on the organization of and the proceedings before certain Flemish administrative courts, BOG 1 October 2014.

38 Art. II.291 Codification 11 October 2013 of the decree provisions on higher education, BOG 27 February 2014.

39 Art. II.292 Codification 11 October 2013 of the decree provisions on higher education, BOG 27 February 2014.

40 At the moment there are 5 Councils for Election Disputes, one for each Flemish province. The Act unifies these Councils into one Council for Election Disputes, competent for the whole of Flanders. 
41 The Council assesses, for example, appeals against the local elections. (Art. 203 Act 8 juli 2011 on the organization of the local and provincial elections, BOG 25 August 2011, err. BOG 6 February 2012)

42 Explanatory Memorandum on the draft Flemish Decree 4 April 2014 on the organization of and proceedings before certain Flemish Administrative Courts, Parl. St. Vl. Parl. 2013-14, nr. 2383/1.

43 This is impossible because the Council for alien law litigation is a federal high administrative court.

44 Art. 14, § 2 Organic laws on the Council of State.

45 There is no cassation appeal possible against judicial decisions of the Council of State, acting as an annulment or suspension court.

46 Art. 14, § 2, in fine Organic laws on the Council of State.

47 CoS 9 July 2015, nr. 231.898; Cos 20 May 2014, nr. 227.464.

48 However, the Council of State can assess facts relating to the cassation procedure as such, for example when determining the existence of force majeure that prevented the timely deposit of procedural documents (Cos 8 November 2000, nr. 90.712, Harmegnies), the interest of the applicant in the cassation appeal (CoS 12 February 2014, nr. 226.392; CoS 21 December 2012, nr. 221.898; CoS 25 September 2012, nr. 220.741; CoS 24 November 2010, nr. 209.193; CoS 30 September 2009, nr. 196.529.), etc.

49 Art. 8 Act 15 September 2006 on the reform of the Council of State and on the creation of a Council for alien law litigation, BOG 6 October 2006.

50 Explanatory Memorandum on the draft Act 15 September 2006 on the reform of the Council of State and on the creation of a Council for alien law litigation, Parl. St. Kamer, 51-2479/o01, 35.

51 Royal Decree 30 November 2006 establishing the cassation procedure before, BOG 1 December 2006, err. BOG 4 May 2007.

52 Regent's Decree of 23 August 1948 establishing the procedure before the Administrative Section of the Council, BOG 23-24 August 1948, err. BOG 8 October 1948 and 21 November 1948.

53 I. VEROUGSTRAETE, Cassatie in civiele zaken (Belgisch recht), in DE WERKWIJZE VAN DE HOOGSTE RECHTSCOLLEGES. PREADVIEZEN, 143 (2007); B. MAES and H. VAN BAVEL, Cassatie in strafzaken (Belgisch recht), in DE WERKWIJZE VAN DE 
HOOGSTE RECHTSCOLLEGES. PREADVIEZEN, 91 (2007); E. KRINGS, Waarom een Balie van Cassatie? in LIBER AMICORUM JOZEF VAN DEN HEUVEL, 61 (1999); X, Cassatierechtspraak vandaag. Rede uitgesproken door procureur-generaal $H$. Lenaerts op de plechtige openingszitting van het Hof van Cassatie op 2 september 1991, RW 137, 139 (1991-1992); A. TUNC Conclusions: la Cour suprème idéale, 30 REVUE INTERNATIONAL DE DROIT COMPARÉ 433, 435 (1978); A. TUNC, Synthèse, 30 REVUE INTERNATIONAL DE DROIT COMPARÉ 5, 14 (1978).

54 Antwerp, Hasselt, Nivelles, Brussels Dutch-speaking, Brussels French-speaking, Leuven, Ghent, Bruges, Liege, Eupen, Mons and Charleroi, Arlon, Namur. Art. 4 Annex to the Judicial Code, territorial scope and office of the tribunals and courts.

55 Antwerp, Brussels, Ghent, Bruges, Liege and Mons. Art. 5 Annex to the Judicial Code, territorial scope and office of the tribunals and courts.

56 Eur. Court H.R., Delcourt v. Belgium, Judgment of 17 January 1970, Series A no. 11, 17, para. 25-26; Eur. Court H.R., Brualla Gomez de la Torre $v$. Spain, Judgment of 19 December 1997, Reports of Judgments and. Decisions 1997-VIII, 2956, para. 37; Eur. Court H.R., Tolstoy-Miloslavsky $v$. United Kingdom, Judgment of 13 July 1995, Series A No 316-B, 78, para. 59; Eur. Court H.R, Monnell and Morris $v$. United Kingdom, Judgment of 2 March 1987, Series A no. 115, 2122, para. 56.

57 Article 14.5 of the International Convenant on Civil and Political Rights as well as Article 2 of Protocol $n^{\circ} 7$ to the ECHR do oblige national States to provide a "high appeal" against judicial penal decisions. The decisions of the Environmental Enforcement Court can be considered to be of a penal nature in the sense of Article $6 \mathrm{ECHR}$, yet no high appeal is possible against these decisions. There is only the possibility to lodge a cassation appeal with the Council of State. However, the Explanatory Report to the Protocol $n^{\circ} 7$ points out that a cassation appeal is to be considered a "high appeal" in the sense of Article 2. The European Court of Human Rights has confirmed this. (ECHR 26 April 2016, Kashlev v. Estonia, §53; ECHR 8 April 2009, Patsouris v. Greece; ECHR 13 February 2001, Krombach v. France, § 96).

58 A relevant disadvantage of a high appeal is that it adds to the length of the judicial procedure and, in this connection, causes a degree of legal uncertainty until the moment a final judicial decision is taken. Other disadvantages are the costs that come with the lodging of an appeal. For an overview of the (dis)advantages of a high appeal: D. HEIRBAUT, Het beroep in burgerlijke zaken: zin of onzin?, TPR, 807, 
822-832 (1994); K. BROECKX, HET RECHT OP HOGER BEROEP EN BEGINSEL VAN DUBBELE AANLEG IN HET CIVIELE GEDING, 428-446 (1995).

59 OVERZICHT VAN HET BELGISCH ADMINISTRATIEF RECHT 948 (A, J. DUJARDIN, M. DAN DAMME, J. VANDE LANOTTE eds., 2014).

6o OVERZICHT VAN HET BELGISCH ADMINISTRATIEF RECHT 965 (A. MAST, J. DUJARDIN, M. DAN DAMME, J. VANDE LANOTTE eds., 2014).

61 In the judicial year 2014-2015. (Annual Report Council of State 2014-2015, 17)

62 J. GORIS, GEORGANISEERDE BESTUURLIJKE BEROEPEN 5O51 (2012).

$63 \mathrm{CoS} 18$ June 2013, nr. 223.955; CoS 15 December 2009, nr. 198.914, De Ridder.; CoS 8 October 2009, nr. 196.699, Glorieux; K. WAUTERS and E. LONCKE, Het administratief beroep: algemeen kader, in HET ADMINISTRATIEF BEROEP 255 (K. WAUTERS ed., 2008).

64 Art. 149 Constitution imposes a judicial duty to state reasons. Art. 151 Constitution imposes a judicial obligation of impartiality. Art. 6 European Convention on Human Rights imposes a judicial obligation of impartiality, the judicial obligation to settle the dispute within a reasonable time, ...

65 This is true for most of the general principles of good governance that have legal value. However, doctrine is divided concerning the question of whether some principles of good governance, such as the principle of legal certainty, have constitutional value. In that case it is impossible to derogate from that principle by legal provision. (I.

OPDEBEEK and M. VAN DAMME, BEGINSELEN VAN BEHOORLIJK BESTUUR 319-320 (2006)).

66 Art. 151 Constitution and Art. 6 European Convention on Human Rights.

67 Art. 152 Constitution.

68 OVERZICHT VAN HET BELGISCH ADMINISTRATIEF RECHT 971 (A. MAST, J. DUJARDIN, M. DAN DAMME, J. VANDE LANOTTE, 2014).

69 Art. 148-149 Constitution, Art. 6 European Convention on Human 
Rights.

70 BOG 12 September 1991.

71 Art. 1-2 Act of 29 July 1991 concerning the explicit motivation of government acts.

$72 \mathrm{CoS} 3$ April 2012, nr. 218.806; CoS 11 February 2010, nr. 200.756, Van Langenhove. For an overview of this legislation: I. OPDEBEEK and A. COOLSAET, FORMELE MOTIVERING VAN BESTUURSHANDELINGEN (2013)

73 OVERZICHT VAN HET BELGISCH ADMINISTRATIEF RECHT 982 (A. MAST, J. DUJARDIN, M. DAN DAMME, J. VANDE LANOTTE eds., 2014).

74 M. VAN DAMME and F. DE KEGEL, INTREKKING VAN DE ADMINISTRATIEVE RECHTSHANDELING (1994).

75 P. VAN ORSHOVEN, M. BOES and B. ALLEMEERSCH, TUSSEN GELIJK HEBBEN EN GELIJK KRIJGEN. GERECHTELIJK RECHT VOOR BACHELORS, 25 (2010).

76 Art. 39/2§1, second paragraph Aliens Act. Under certain conditions, the Council can annul the contested act and send the case back to the GCRS, which will have to take a new administrative act.

77 The applicant can also request the suspension of the contested act, as an adjunct to the annulment.

78 Art. 16.4.19§4 Decree of 5 April 1995 containing general provisions on environmental policy, BOG 3 June 1995.

79 Art. 4.8.2. Flemish Codex on Zoning Law.

80 Art. 37 Flemish Act 4 April 2014 on the organization of and the proceedings before certain Flemish administrative courts, BOG 1 October 2014.

81 Art. II.292 Codification 11 October 2013 of the decree provisions on higher education, BOG 27 February 2014.

82 One must bear in mind that in most cases, there is no administrative appeal prior to the appeal with the administrative high court. In those cases there is no "filter" system, in the sense that these cases could be handled on an administrative level without any need for a judicial treatment. Therefore, it is not unreasonable to assume the percentage of "appeal" cases against decisions of high administrative 
courts would still be considerably high.

83 According to Article 145 of the Belgian Constitution, the "legislator" is competent to create administrative courts. The Constitutional Court has confirmed that only the federal legislator can regulate the competence of the administrative court, except when Article 10 Special Law on Institutional Reform is applicable. (Constitutional Court, 27 January 2011, nr. 8/2011, B.8.10.2.; Constitutional Court, 14 May 2003, nr. 58/2003; Constitutional Court, 30 April 1997, nr. 25/97) This means that the regional legislator is competent to create administrative courts only when he exercises his so-called "implicit powers", i.e. under the condition that the regulation is necessary for the exercise of a regional competence, that the matter at hand is susceptible to a differentiated regulation and that the impact of the regional regulation of the federal matter is only marginal. (Constitutional Court, 27 January 2011, nr. 8/2011, B.8.10.2.)

๑) Boom juridisch 